\title{
Rural Women's Empowerment through Employment from the Beijing Platform for Action Onwards
}

\author{
Paola Termine and Monika Percic
}

\begin{abstract}
This article provides a critical analysis of the conceptualisation of women's empowerment through employment (and later decent work) from the Convention on the Elimination of All Forms of Discrimination against Women, the Beijing Platform for Action through to the Millennium Development Goals, the Decent Work Agenda and current proposals for the post-2015 Development Agenda. The article focuses on the context of rural women. Through a historical overview of the increasing importance placed on employment and the 'world of work' for poverty reduction and women's empowerment within the development discourse, the article analyses the implications and gaps of prevailing approaches. The article also provides recommendations to enhance the potential of rural employment and decent work in promoting women's empowerment, including with specific reference to the debates around the post-2015 Development Agenda.
\end{abstract}

\section{Introduction}

\subsection{The gender gap in rural employment}

The recent global economic, food and political crises, and the impact of climate change, pose important challenges in eliminating women's disadvantage and closing the gender gap in employment, especially in rural areas. Most rural people rely mainly on income from their labour for their livelihoods. The majority of them are, however, 'working poor' - which means that they do not earn a living wage and income (including from self- and wage employment) despite working full-time - and are in 'vulnerable employment'.

This is disproportionately the case for women compared to men. In fact, data indicate that in 2012 women comprised about 33 per cent of the agricultural labour force worldwide, ranging from less than 10 per cent in Latin America and the Caribbean to more than 60 per cent in South Asia and sub-Saharan Africa (ILO 2014a). Women are overrepresented in vulnerable employment and among the working poor, especially in sub-Saharan Africa and South Asia where 85 per cent and 82 per cent of women, respectively, are in vulnerable employment (ILO 2014a).

The world of work is a domain of stark gender inequalities, in both rural and urban areas. Wage and pay gaps; gender segregation in low pay, low status and insecure occupations and industries ('feminisation' of labour); overrepresentation within unpaid work (such as in contributing family labour) and casual labour; the triple burden of productive, reproductive and community work, with its consequent time poverty; disadvantages in education, skills and training, with resulting lower human capital and employability; restrictive social norms hindering mobility and access to markets; no provisions for maternity leave and breastfeeding time; and lower levels of representation in apex organisations such as trade unions; are among the areas where the gender gap in rural employment is most evident. Women's disadvantage is also present with respect to opportunities to access decent work through self-employment as agricultural producers, due to their lower access to and control of natural productive resources such as land, water, trees and livestock, and lower access to training and to complementary productive resources, including finance and technology, which also have negative impacts on their labour productivity.

\subsection{Some of the (mixed) accomplishments to date Over the past two decades, there has been some progress in women's empowerment through decent work and productive employment. Yet, the main challenges remain. Since 1995, the gap in labour market participation rates between men and women}


has only marginally decreased, from 52 per cent for women and 80 per cent for men in 1995 to 50 per cent for women and 77 per cent for men in most recent estimates (ILO 2014b). Vulnerable employment saw a more significant reduction: in 1995, 58 per cent of women and 53 per cent of men were classified as in 'vulnerable employment', most recent figures are 46 per cent of women and 44 per cent of men. However, despite the percentage of countries offering 14 weeks' or more maternity leave increasing from 38 per cent in 1995 to 51 per cent in 2015 , access to adequate maternity protection is still unavailable for more than 800 million women workers globally (41 per cent of all women), the majority of whom live in rural areas. ${ }^{2}$

Although there have been changes in men's attitudes towards contributing to unpaid care and domestic work, in many parts of the world women still continue to disproportionately bear the burden of reproductive responsibilities and community work, particularly so in rural areas. This severely limits the time they have available for productive and paid work, and contributes to reinforcing the perception of women as secondary workers confined to lower paid, part-time or seasonal jobs (FAO 2011). A gendered pay gap remains persistent, with women earning on average a quarter less than men's wages (ILO 2013). Violence against women is a major factor undermining their dignity and access to decent work: about a third of all women are victims of physical and/or sexual violence, which may limit their choice of sectors and occupations and affect their safety at work. Finally, 20 years on from the Beijing conference, women own and manage more businesses (over 30 per cent) but these still tend to be micro and small enterprises. Women also occupy nearly 20 per cent of board seats globally, but only five per cent of the CEOs of the world's largest corporations are women (compared to almost zero in 1995) (ILO 2015).

In terms of policy, legislation and the ratification of international labour standards, there has been notable progress. For example, since 1995, the Equal Remuneration Convention, 1951 (No. 100) increased from 126 to 171 ratifications and the Discrimination (Employment and Occupation) Convention, 1958 (No. 111) from 122 to 172 ratifications. Despite this progress, a lot more needs to be done to achieve gender equality. Through the provision of decent work, poor rural women can be empowered economically, socially and politically. This may have lasting effects not only on their individual and household livelihoods but can also greatly contribute to a long-lasting gender equality in the world of work.

\section{Historical overview}

\subsection{Convention on the Elimination of All Forms of Discrimination against Women (CEDAW)}

The Convention on the Elimination of All Forms of Discrimination against Women (CEDAW 1979) ${ }^{3}$ is the fundamental international legislation on gender equality, indicating an agenda for national action to end discrimination against women. It is the only human rights treaty that affirms the reproductive rights of women and targets culture and tradition as influential forces shaping gender roles and family relations. For rural women's employment, several articles are of relevance, notably, Article 11 on employment and Article 14 on rural women.

Article 11 of CEDAW aims to ensure that states take all appropriate measures to eliminate discrimination against women in employment and to ensure equal enjoyment of rights for both women and men. It advocates for the right to work to be seen as an inalienable right of all human beings strongly echoing the United Nations (UN) Declaration on Human Rights. It also includes provisions for the prevention of discrimination against women on the grounds of marriage or maternity, for example prohibiting dismissal on the grounds of pregnancy or of maternity leave and calling for maternity leave with pay or with comparable social benefits without loss of former employment, seniority or social allowances. Although not explicitly targeted, Article 11 is very relevant for rural women concentrated in vulnerable and low productivity employment, and who face additional hardship related to their responsibilities for unpaid domestic chores and care work (FAO 2013). ${ }^{4}$

By focusing on the specific rights of rural women, Article 14 encourages states to consider particular obstacles that rural women face and their significant roles for the social and economic wellbeing of their families and the wider community and acknowledges rural women's work in the non-monetised sectors of the economy. It also requires states to take all appropriate measures to ensure that rural women benefit from rural development, including through equal access to productive assets (i.e. land and employment), financial assets (i.e. agricultural credit and loans), education and training, and to adequate health-care facilities and social security programmes. It also requires enabling provisions for rural women to organise in self-help groups and cooperatives and enjoy adequate living conditions (i.e. access to basic infrastructure, transport and communication).

With explicit recognition of the importance of conditions of work and of the value of women's 
reproductive work in Articles 11 and 14, and provisions for education (Article 10), ${ }^{5}$ economic and social benefits (Article 13), law (Article 15) and marriage and family life (Article 16), CEDAW set the stage and directly contributed to discourses and thinking processes that led to the Decent Work Agenda.

\subsection{The Beijing Platform for Action}

The landmark Fourth World Conference on Women (Beijing, 1995) substantially advanced the discourse on women's empowerment in the global arena, through the Beijing Declaration and the Beijing Platform for Action (BPfA). The conference's vision focused on empowerment as a sociopolitical process which would change economic, social and political power between and across individuals and groups, eliminating all obstacles to women's active participation in all spheres of public and private life through a full and equal share in economic, social, cultural and political decision-making. ${ }^{6}$ This implied equality between women and men at all levels (i.e. in the household, the workplace and the wider national and international communities) as a human right and as a condition for social justice.

The BPfA aimed to contribute to rural women's empowerment through employment with a focus on poverty, the economy, power and decision-making, education and vocational training, and health. The BPfA acknowledged that women contribute to the economy and to poverty reduction through remunerated and unremunerated work at home, in the community and in the workplace, and that rural women face a greater risk of falling into poverty than rural men. The BPfA recognised the barriers women face to entering labour markets and their limited economic decision-making power which perpetuates their subordinate position. It also recognised that girls are engaged in heavy domestic work from an early age which impedes their schooling with detrimental long-lasting consequences on all aspects of their future lives (FAO 2010a, 2010b).

To overcome these gendered inequalities and discrimination, the BPfA proposed a range of measures, including: the promotion of women's economic rights and independence, such as access to employment and control over economic resources; provision of business services, training and access to markets, information and technology, particularly to low-income women; the elimination of occupational segregation and all forms of employment discrimination; the promotion of harmonisation of work and family responsibilities for women and men; and ensuring women's equal access to, and full participation in, power structures and decision-making. The BPfA recognised the interconnectedness of rural poverty, gender discrimination and rural women's greater hardships in advancing economically, particularly those working in the agricultural sector. It also recognised that women's empowerment is key to poverty eradication through better employment and incomegeneration opportunities.

CEDAW and the BPfA have significantly informed subsequent global discourse on gender equality and conditions of employment, including the Decent Work Agenda, the Millennium Development Goals and the proposed Sustainable Development Goals.

\subsection{The Decent Work Agenda}

Recognising the importance of both quantity and quality of employment, the International Labour Organization (ILO) has promoted the concept of decent work since 1999. The Decent Work Agenda (DWA) was subsequently endorsed by the UN system, and adopted as a UN global goal. Responding to the ILO goal to promote opportunities for women and men to obtain decent and productive work, in conditions of freedom, equity, security and human dignity, ${ }^{7}$ decent work involves opportunities that deliver a fair income, a secure workplace and social protection for families; good prospects for personal development and social integration; freedom for people to express their concerns and to participate in the decisions that affect their lives; and equality of opportunity and treatment for all women and men. ${ }^{8}$

The DWA is structured along four pillars, all contributing to women's empowerment. Pillar I on employment and enterprise development concentrates on the availability of an adequate number of productive, quality jobs which provide for a living wage. ${ }^{9}$ This includes increasing labour productivity, by enhancing human capital through vocational education and training, promotion of entrepreneurship, and where needed, support to livelihoods diversification. Gender equality, besides being an intrinsic value and a right in itself, makes economic sense through the more efficient use of resources. Pillar II on social protection refers to protection from work-related injury and from lack of income due to unemployment, illness or age. Social protection has a very important role in contributing to social transformation towards gender equality, for example by providing services that address reproductive and care work, and by addressing 


\section{MDG 1: Eradicate Extreme Hunger and Poverty}

Target 1B: Achieve full and productive employment and decent work for all, including women and young people
1.4 Growth rate of labour productivity (gross domestic product (GDP) per person employed)

1.5 Employment-to-population ratio

1.6 Proportion of employed people living below the poverty line (working poor)

1.7 Proportion of own-account and contributing family workers in total employment (vulnerable employment rate)

\section{MDG 3: Promote Gender Equality and Empower Women}

Target 3A. Eliminate gender disparity in primary and secondary education, preferably by 2005 , and in all levels of education no later than 2015
3.2 Share of women in wage employment in the non-agricultural sector

Source Authors' adaptation from the UN MDG Indicators website. ${ }^{10}$

women's immediate income constraints. However, more than 70 per cent of the world population lacks proper social protection (ILO 2014d), the majority of whom are likely to be poor rural women.

Pillar III on standards and rights at work focuses on respect of the core labour standards (or fundamental principles and rights at work), which are: (1) abolition of child labour; (2) elimination of all forms of forced or compulsory labour; (3) freedom of association and the recognition of the right to collective bargaining; and (4) elimination of any discrimination in respect of employment and occupation. This last principle refers to providing equal opportunities in accessing employment and career development without consideration of gender, age, ethnicity, race, religion, sexual orientation or other factors. Core labour standards are not widely applied and enforced in rural areas due to the informality of the sector (especially in its small-scale operations). In addition, in some countries labour laws do not cover informal and/or agricultural workers, the selfemployed and contributing family workers, among whom women are overrepresented. Pillar IV on governance and social dialogue is about participation in decision-making affecting the world of work and representation of interests in negotiations, including through collective bargaining. Good governance is not only a means to achieve decent work but also an end in itself towards empowerment and social inclusion. There is an important gender gap in women's representation and leadership in member- based organisations, formal and informal, and their capacity to participate in collective action, especially so in rural areas.

The DWA contributes to women's empowerment as conceptualised in the BPfA and CEDAW. Yet, the DWA suffers from a formal and urban economy bias, as its implementation has focused mainly on urban employment, with more limited experience in rural and informal types of occupations and activities. In addition, it does not take explicitly into consideration women's triple work burden and their time poverty which obstructs their active participation in decent work and full and productive employment.

\subsection{The Millennium Development Goals (MDGs)}

Launched in 2000, the Millennium Development Goals (MDGs) prioritised eradication of extreme hunger and poverty (through MDG 1) and directly aimed to promote gender equality and women's empowerment (through MDG 3). In 2008, the centrality of decent and productive work for all, including women and youth, for addressing global poverty and hunger was recognised through the inclusion of a specific Target (1B) within the MDG 1 .

Table 1 shows the indicators relevant to decent work and promotion and measurement of progress on women's empowerment and gender equality within the MDGs. These indicators fall short of expectations with regard to measuring impact on rural women's 
empowerment. First of all, the indicators under Target $1 \mathrm{~B}$ are not age- and sex-disaggregated, despite the explicit target on women and young people. In addition, indicators 1.4 and 1.5 are not very informative with respect to progress in achieving decent work. And, most significantly, indicator 1.7, which should indicate progress in terms of conditions of employment, is not adequate to measure decent work, especially with reference to rural women engaged in productive work. In fact, vulnerable employment defined by the ILO based on status in employment ${ }^{11}$ as including own-account workers (selfemployed) and contributing family members, is used as a proxy to indicate workers less protected from job insecurity, and with low earnings, low productivity and difficult conditions of work that undermine workers' fundamental rights (ILO 2010).

\section{The problem with indicator 1.7 is that in a rural} context it loses significance, as self-employment of agricultural producers is more often associated with higher social and economic status than being a salaried worker in agriculture. This is because self-employment in agriculture implies ownership of and access to important means of production, such as land. ${ }^{12}$ Along the same lines, being a contributory family worker may imply benefiting from a share of these assets, although within the limitations and uncertainty of an unregulated employment relationship. Consistently, hiring out labour may be a 'last resort' option for agricultural households. Therefore, the employment status which is often the most vulnerable in the rural context is that of waged workers. Similar observations can be made with respect to indicators selected for MDG 3, where focusing on the share of women in wage employment in the non-agricultural sector downplays the importance of women's productive engagement in agricultural activities worldwide, and its significance for their economic, social and political empowerment.

\section{Proposals for the Sustainable Development Goals (SDGs)}

The Sustainable Development Goals (SDGs) are a set of universal goals and respective targets that, building on the MDGs, aim to guide the international development agenda until 2030 and will replace the MDGs at the end of 2015. The current SDGs proposal - expected to be adopted in September 2015 - contains 17 goals with 169 targets, with respective indicators still under development. ${ }^{13}$ The SDGs represent a definite step forward in recognising the importance of decent work for poverty eradication and women's empowerment, towards social justice.
In fact, among the SDGs most relevant for women's empowerment through decent work are Goal 5 - which aims to 'achieve gender equality and empower all women and girls' - and Goal 8 - on the promotion of 'sustained, inclusive and sustainable economic growth, full and productive employment and decent work for all'. As with the MDGs, targets and indicators will determine the strength of the commitments and the extent to which progress can be measured. As mentioned, indicators are still being discussed, but there are authoritative proposals to draw from. For example, the Sustainable Development Solutions Network $(2015)^{14}$ proposes as an indicator for Goal 5 the 'average number of hours spent on paid and unpaid work combined (total work burden), by sex', which could be very informative with respect to women's empowerment. However, to avoid averages masking reality, it would be important to further disaggregate it spatially, to be able to distinguish between rural and urban contexts, given their marked differences in terms of the incidence of productive and reproductive work.

The indicators that will be finally selected for Goal 8, concerned most directly with employment and decent work, will be most important to monitor how decent work contributes to enabling rural women's empowerment. It would be important to insert measures of decent work that are relevant for agriculture, the rural economy and the informal sector, that consider women's double or triple burden of productive, reproductive and community work, and that monitor the specific challenges faced by youth in entering the labour market and accessing decent jobs. A proposal for a composite indicator on decent work, yet to be developed, should include at the minimum: ratification and implementation of core labour standards; employment rates disaggregated by age, sex and spatially (urban/ rural), by formal and informal arrangements and by sector of activity; and women's and men's labour market participation rate.

To ensure that the dimensions contributing to women's empowerment in agricultural self-employment are fully captured, indicators incorporating security of tenure over land and other natural resources, and the percentage of people (disaggregated by sex) who perceive that their rights are recognised and protected, ${ }^{15}$ could be included under Goal 2 - which aims to 'end hunger, achieve food security and improved nutrition and promote sustainable agriculture'.

Employment has been considered an important element for women's empowerment since the 
development of CEDAW, which brought a strong human rights perspective. The BPfA retained the human rights approach and widened its scope to highlight some additional work-related issues such as women's time poverty due to their work burden, gendered inequalities in decision-making and high informality of work. Yet, CEDAW and the BPfA had a rather limited recognition of the importance of collective action to overcome structural constraints and build collaborative spaces that would promote women's empowerment in a broader sense. The importance of labour relations and social dialogue were, for example, not explicitly taken into account in either of them, and women's organising was only considered as a means to overcome immediate constraints to economic empowerment, underestimating its potential significance for social and political empowerment.

The DWA has marked a major development in bringing together the economic, social and political aspects of work and employment. It set universal standards for decent work and social inclusion with the aim of equally benefiting women and men, particularly those most disadvantaged. The DWA's weaknesses may, however, lay in its application in rural areas and in addressing the close relationship of women's productive and reproductive roles, the interplay between the workplace and the household, and how these dynamics affect decent work.

Despite these breakthroughs, the importance of labour and human rights as the basis of empowerment was not adequately integrated in the MDGs, and is only marginally addressed in the SDGs proposals. Therefore, more needs to be done to ensure that the human rights dimension of women's empowerment is included in the SDGs indicators, financing mechanisms and in the monitoring of their implementation progress.

\section{Conclusions and recommendations}

The inclusion of decent work and full and productive employment among the SDGs is an important development in the global discourse to advance the goal of gender equality and women's economic, social and political empowerment. Further progress could be made in making the human rights approach more prominent, especially at the indicator level, to ensure its importance is retained in implementation and monitoring and not diluted out, as was the case with the MDGs. It would therefore be important to ensure that indicators concerning fundamental principles and rights at work, regarded as human rights, be retained as core measures of decent work.
In terms of progress on rural women's empowerment through decent work and productive employment, however, gender equality is still a distant reality. Rural women are often exposed to a double disadvantage based on their gender and location, and young women often face additional barriers in accessing decent work and productive resources. It is important to ensure specific targeting and disaggregated indicators to monitor progress for the most disadvantaged categories, to ensure action is focused where need is most intense and that specific challenges faced by women are addressed.

Fundamental for triggering women's empowerment processes is the development of women's awareness and self-consciousness. Enhancing women's intra-household decision-making and bargaining power, and promoting shared responsibilities is important as the household is the key transmission mechanism of economic and social change from the broader environment to the individual. Intra-household decision-making and power are fundamental in determining choices and incentives throughout the life cycle of women. The involvement of agents of sociocultural change (such as women, men, traditional authorities), and joint collective action, is fundamental for broader and sustainable sociocultural transformations.

Supporting women's collective action and their participation and leadership in stronger and more representative rural institutions are important strategies to promote women's self-organisation and empowerment. Rural member-based organisations can be instrumental in overcoming some of the constraints that small agricultural producers, and especially women, face, such as limited access to markets, conflicts over management of natural resources, and limited access to information, services, inputs and technology, and can provide fora for women's self-organisation and collective action. Access to formal and informal groups and networks enables rural women to access markets and other productive resources as well as to gain power, influence and valuable information, which may pave the way for deeper changes.

Fostering an enabling environment for rural women's economic, social and political empowerment at all levels (national, regional, local/community and household), includes government efforts to enhance women's access to decent work through policy and legislation; extension of social protection; and better labour markets governance and social dialogue.

Legislation, policies and programmes need to ensure that women and men have access to the same 
opportunities, addressing their different needs and constraints. In particular, this means addressing women's barriers to accumulating human capital and accessing economic opportunities because of lower incentives in investing in girls' education, social barriers to school attendance, time poverty, reduced mobility, reproductive and community roles conflicting with productive activities, and industry segregation. This should be achieved by facilitating women's access to education and training, especially in non-traditional women's occupations and entrepreneurship; and by addressing inequalities in accessing complementary inputs and productive resources, services, information, markets and social protection. To maximise its transformational impact and empowering effect, training should include capacity building on rights and citizenship, and providing opportunities for women to develop and exercise collective action. Legislative, policy and programmative frameworks need to have sound monitoring and evaluation systems to ensure efficient implementation on the ground.

The restriction on women's ability to own and inherit assets and to control resources lies at the root of agricultural productivity gaps in many countries and disempowers women. It is therefore important to address it through reforms such as joint ownership in marriage, increasing women's ability to use land in accessing economic opportunities, and mandatory joint land titling.

\subsection{Some specific recommendations for the SDGs and the post-2015 development agenda}

The SDGs and the post-2015 development agenda represent an important opportunity to promote women's empowerment. Whether this is realised

\section{Notes}

* The views expressed in this article are those of the authors and do not necessarily represent those of the Food and Agriculture Organization (FAO) of the United Nations.

1 'Vulnerable employment' is defined by the ILO as a sum of own-account workers and contributing family workers.

2 ILO reports that, at the same time, states are increasingly recognising men's care responsibilities. In 1994, 28 per cent of countries surveyed provided some form of paternity leave, compared to 47 per cent in 2013 (ILO 2014c).

3 The CEDAW has had almost universal ratification with 180 signatories.

4 Specifically, Article 1 1's provisions (a), (b), (c) and (d) on equal employment opportunities, conditions, depends on a strategic approach at all levels that will efficiently address the most important constraints faced by rural women of all ages in terms of their access to decent work and productive and full employment. A broad-based agreement on the principles and evidence of impact of what makes rural employment and decent work policies contribute to women's empowerment is still limited. Promoting gender-equitable rural employment requires action at the individual, household and institutional levels. At the individual level, a deep understanding of the determinants (demand and supply factors) of women's participation in labour markets, reproductive and community work is needed. Understanding whether rural women work mainly as a coping strategy at times of crisis (as data show is mainly the case in Asia and Latin America) or whether they are indeed primary workers (as in Africa) is important in implementing the appropriate measures. Intra-household division of responsibilities, allocation of resources and expectations are important factors to consider in the analysis.

Women's empowerment through decent work is an important component for the achievement of the proposed SDGs. Explicit inclusion of rural women at the indicator level is important to ensure they are fully considered as beneficiaries and agents of change. Specifically, in Goal 8, rural populations, and women in particular, need to be adequately acknowledged given their greater disadvantage in accessing decent work, compared to urban women. Likewise, many of the Goal 8 targets, and related indicators, should be sex-disaggregated, particularly so Targets 8.6 and 8.7. Engendering Goal 8 would assist in adequate implementation and measurements of these targets for both women and men equally.

remuneration and vocational training, complement and expand on Article 14's provisions (c), (d) and (e) on social security, training and education, and selforganisation and cooperatives.

5 Article 10 emphasises, inter alia, that the same conditions for career and vocational guidance, for access to studies and for the achievement of diplomas in educational establishments of all categories apply equally to all, including rural women.

6 'The objective of the Beijing Platform for Action is the empowerment of all women. The full realisation of all human rights and fundamental freedoms of all women is essential for the empowerment of women'. Source: Fourth World Conference on Women website www.un.org/womenwatch/daw/beijing/ fwcwn.html. 
7 International Labour Conference, 87th Session, Geneva 1999.

8 Definition from www.ilo.org/global/topics/ decent-work/lang--en/index.htm.

9 Although there is no agreed definition of 'living wage', for the ILO it can be defined according to Conventions No. 95 and No. 131, and

Recommendations No. 131 and No. 135 and the Universal Declaration of Human Rights (Article 23): wages and benefits paid for a standard working week should meet at least legal or industry minimum wage standards and always be sufficient to meet basic needs of workers and their families and to provide discretionary income.

10 http://mdgs.un.org/unsd/mdg/Default.aspx.

11 The status in employment describes the type of economic risk and authority which workers have in their jobs, as reflected in their explicit or implicit contract of employment. The concept of status in employment is defined by the resolution concerning the International Glassification of

\section{References}

FAO (2013) CEDAW Guidelines: A Tool for Gendersensitive Agriculture and Rural Development Policy and Programme Formulation, Rome: Food and Agriculture Organization of the United Nations

FAO (2011) The State of Food and Agriculture 20102011. Women in Agriculture: Closing the Gender Gap for Development, Rome: Food and Agriculture Organization of the United Nations

FAO (2010a) Gender Dimensions of Rural and Agricultural Employment. Differentiated Pathways out of Poverty: A Global Perspective, Rome: Food and Agriculture Organization of the United Nations

FAO (2010b) Breaking the Rural Poverty Cycle: Getting Girls and Boys out of Work and into School, Policy Brief, Rome: Food and Agriculture Organization of the United Nations

ILO (2015) Women in Business and Management Gaining Momentum: Abridged Version of the Global Report, Geneva: International Labour Office

ILO (2014a) Global Employment Trends 2014: Risks of a fobless Recovery, Geneva: International Labour Office
Status in Employment (ICSE), known as ICSE-93, adopted at the 14th International Conference of Labour Statisticians, www.ilo.org/global/statisticsand-databases/statistics-overview-and-topics/ status-in-employment/current-guidelines/lang-en/index.htm (accessed 30 September 2014).

12 Yet this does contradict the fact that women producers own and control less land and have more limited access to inputs, seeds, credit, and extension services, compared to men, and that women working as contributing family workers may be in a disadvantaged position compared to male members of the household with respect to benefiting from income, resources and in terms of work burden.

13 See UN SDG website: https://sustainabledevelopment.un.org/topics/ sustainabledevelopmentgoals.

$14 \mathrm{http}: / /$ unsdsn.org/what-we-do/monitoring-thesdgs (accessed 19 March 2015).

15 As proposed by the Sustainable Development Solutions Network (2015).

ILO (2014b) World of Work 2014: Developing with fobs, Geneva: International Labour Office

ILO (2014c) Maternity and Paternity at Work: Law and Practice Across the World, Geneva: International Labour Office

ILO (2014d) World Social Protection Report 2014/15: Building Economic Recovery, Inclusive Development and Social fustice, Geneva: International Labour Office

ILO (2013) Equal Pay, An Introductory Guide, Geneva: International Labour Office

ILO (2010) Women in Labour Markets: Measuring Progress and Identifying Challenges, Geneva: International Labour Office

SDSN (2015) 'Indicators and a Monitoring Framework for the Sustainable Development Goals. Launching a Data Revolution for the SDGs', a report by the Leadership Council of the Sustainable Development Solutions Network, revised working draft (version 6), 18 February, Paris: Sustainable Development Solutions Network 